Featured Essay

\title{
To Build or to Destroy? The Philippine Experience with Walls and a Southeast Asian Perspective ${ }^{1}$
}

Ranhilio Callangan Aquino

\section{When is it a Wall?}

There are threads that undoubtedly bind us, but we Southeast Asians are accurately described as pluricultural and multi-ethnic. We have lived thus for several centuries now and most of the histories of the nations that constitute our part of the globe bear the marks of attempts of various colonizers to deal with ethnicity and to make us more "manageable" by bringing us Islam first, then Christianity - though in various forms as well, and attempting to cope with the Babel of our many languages through some imposed common medium-in the case of the Philippines, Spanish, marginally, and English, considerably!

This brings me to my first question: Have we lived amidst walls "already there"? And was it the colonizers' "manifest destiny" to tear down these walls? Or did they in fact build walls? I stand by the position that in our part of the world, we live with walls that have already been there, walls that, in Levinas' own peculiar but powerfully suggestive terms, are an-archic, in the sense that they are an-arche, older than any design and predating any prescription. The fact for us Filipinos seems to be that we have lived with walls and we are not attributing these walls to our colonizers alone. We recognized our mountain regions as walls where dwelt tribes with customs and practices of their own-including, for some time in the past, the dreaded show of machismo that took the form of head-hunting. We recognized our southern provinces as walled by the religion, the culture and the aspirations of Islam. Walls then have been a fact of national existence, and wherever positive law has attempted to tear down these walls, we have had more trouble than gain. This of course makes us ask whether these are indeed "walls"-although it is clear that in other parts of the world, they have been walls. Isn't "walls as a problem" ethnocentric in motive?

To ask when a "wall" is a "wall" is to ask about the architectonics of power, if Foucault is not terribly wrong. What counts as a wall? Is a different language a wall? Is a different religion a wall? Obviously when the Spaniards made the Philippines a colony of Spain they counted as a wall the Catholic faith

1 This paper was read at the International Critical Legal Studies Conference 2007, Birkbeck College, University of London. 


\section{TO BUILD OR TO DESTROY?}

that sequestered the faithful from the perverse practices and skewed beliefs of unbelievers. But it is equally obvious that for our Muslims in southern Philippines, the walls-either of fortification or cathedral-left as theirs everything that was without. Nowhere is this more evident than in the history of Manila, our capital city. The walled city marked the Spanish enclave-but the expanse without was the domain of the Muslim rajahs and datus!

In our experience, a wall can inspire awe and reverence, as when it is the wall of a church or the wall of a mosque. The construction of the first walls of a home is, in our culture, an occasion of celebration-in essence, the celebration of family. True, it effectively keeps certain people in and excludes others but most of the time it will be one's own reticence and respect for what another holds sacred that keeps one out of the holy precincts of another. Walls have also been for us articulations of the right of self-determination. We are still struggling with the issue of self-determination of indigenous cultural communities vis-à-vis secession. To be sure, there are some Filipinos who believe that the right to self-determination necessarily entails the right to secession. Others, however, are averse to the prospect of "tribalization" while fully cognizant of the boundaries that walls draw.

I therefore advance the following positions:

1. From the Philippine experience, national life has always been a life with walls, and these walls have not necessarily been a bane. They have been assertions of ethnicity, religious identity and cultural particularity. And they are walls not because those "within" raised them to keep others without. They are an-archic in Levinas' sense, admitting of no definite assignation as to their beginning in time, nor susceptible of attribution as to their erection. I would like to be able to say that the diversity has all blended so well into a distinct Filipino culture and a seamless legal framework, but I cannot and will not, because this is not the case. Our government has had to quell pocket movements of secession; it has had to delineate an autonomous region in the south. The challenge for us has not been to tear down walls but to be one nation that recognizes walls.

2. In the context of international law, we note that the basicprinciples of international law are wall-building. The principle of the sovereign equality of States is very clearly the positive side of the proscription of aggression and any form of derogation of the territorial and political integrity of any State. In fact, the most fundamental wall to my mind in international law is the legal concept of territory, raised to a transcendental level by the concept of sovereignty. The same thing can quite clearly be said of the fundamental precept of the United Nations Charter that steers the UN away from the inherently domestic affairs of any State. 
3. But we have also erected walls in our country that keep dark secrets, such as the walls of military camps where dissidents were kept in solitary confinement during the period of martial law, and walls of safe-houses even to this day where political mavericks are confined. Just as international law has refused to recognize political sovereignty as a wall that keeps out humanitarian intervention, particularly when an ethnic group is grossly and arrantly abused by its own government, our own national institutions-governmental and non-governmental-have recognized these walls that hide evil secrets and has taken some measures if not at tearing them down at least of tunneling beneath them. Thus, recently, the Supreme Court of the Philippines itself hosted a summit of academics, legislators, law-enforcers, prosecutors and judges to address the problem of "extra-judicial executions and enforced disappearances." The walls of safehouses, un-registered and ad hoc places of confinement could not be allowed to remain fortresses of rights-violations.

When walls are a declaration of place, an assertion of space it is folly to ignore them or worse to ram them down. But when walls become bastions within which the helpless are subjected to rack and wheel, then no wall-no matter how lofty its title (sovereignty, domestic affair, internal security) should ever be so impermeable that it will not crumble beneath the collective will that walls are to protect and not to provide shelter to the iniquitous.

If this sounds like moralizing, I do not apologize for it. After all, international law, in the last decades, particularly through that growing corpus of expressions of collective sentiment rather infelicitously called "soft law" has made clear that solidarity and justice are not some idle philosophers' dream but legitimate goals of a global legal order!

\section{Walls and terrorists}

The Philippines has recently enacted what is known as the "Human Security Act of 2007" or Republic Act No. 9327. A statute constructs a wall: it must make clear what it covers and what it excludes. It can therefore not mirror the reality that there is no consensus about what terrorism is. In this respect, the positivism of the law is helpful. Our Legislature posits terrorism as "any of the (enumerated) acts committed by anyone who wishes to sow widespread fear and panic with the intention of coercing the government into doing what is illegal." Of course, the statute by this token excludes the possibility that when its armed agents sow wide-spread fear and panic with the intention of making them submit to what they would otherwise not submit, it cannot be engaged in terrorism.

Walls have been erected to keep out terrorists, but that is one reading of the text of that phenomenon we call terrorism (and anti-terrorism). We 


\section{TO BUILD OR TO DESTROY?}

must pay attention to the claim of those whom we have labeled terrorists that the walls that the powerful and the majority have constructed were the provocation of terror and that the regrettable destructiveness that we lament is but the bitter fruit of this provocation. Saying this is not denying that there are certain acts of thoughtlessness for which there can be no moral and legal justification: such as blowing up commuter trains at peak hours or strapping bombs to women and children who then become bi-pedal explosives. But it warns us against privileging our position and casting into suspicion (if not outlawing) all others that are in dissent.

Are we therefore faced with impermeable walls of irreconcilable opinions, beliefs and fundamental allegiances? Possner does not think much of Habermas' discourse theory of law and of democracy, pointing out that the speech-situation he demands is virtually impossible of attainment. I sense the same resistance to Habermas at this conference. But I do think that when we make such proposals as that made by Prof. Joele who convincingly asks us to suspend suspicion rather than suspend for suspension, I discern a concession, albeit unwilling, to Habermas. We suspend our suspicion of those we label terrorists - and this suspension of suspicion, of disbelief, is a willingness to lend a hearing, willingness to grant the possibility of rationality. I do not think that it is feasible either in law or in any other human enterprise to give up totally on rationality. What has however undoubtedly fueled much of what today besieges us as "terrorism" are claims at the exclusive possession and exercise of rationality.

The State makes claims, and so do those it outlaws as terrorists. If indeed there is no way beyond this impasse then all that seems to be left is strategic action, as Habermas warns. I do not see any other option. Here, I believe, is where any meaningful discourse on terrorism may take off. State and dissident or oppositionist alike must be ready to justify their claims when challenged and to support them. Consequently, both must be willing to suspend suspicion. And both State and dissident are as capable of assuming the imperial, terrorist posture of refusing to justify claims, or even so much as to entertain question and challenge.

Labeling the government as terrorist, or the United States (and the members of the so-called "coalition of the willing") will not help. It will only transfer the rhetoric from one side to the other. We should have realized this already since Hegel. In other words, whichever side one stands when the wall is impermeable in respect of claim and justification, one is no better off. I think that equally important is refusing to give up on the possibility of consensus, or at least the possibility of agreeing that violence-whether it be juridified as "state-force" or criminalized as "terrorist"-really keeps two parties talking past each other, no matter that they may seem to be addressing each other, because terrorists really do not address. They demand submission! 